CHAPTER XXIV

\title{
ACCESSION TO ECSC AND EURATOM COMMUNITIES
}

\section{A- ACCESSION TO THE COMMUNITIES}

When joining the Community a new Member State acceds simultaneously to the EEC and the two other Communities. In view of their separate legal existence this is purely a technical question but an applicant cannot be selective and join one or two only but not all three.

Turkey, as a coal producing country has an interest in the ECSC and, as a progressive country has to consider the application of atomic energy for peaceful purposes. Accession to both would be beneficial.

\section{B- AIMS OF THE ECSC AND EURATOM TREATIES}

The aims of the European Coal and Steel Community are to ensure: -

(a) an orderly supply to the common market, taking into account the needs of third countries;

(b) that all comparably placed consumers in the common market have equal access to the sources of production;

(c) the establishment of the lowest prices while allowing necessary amortisation and normal return on invested capital;

(d) the maintenance of conditions encouraging the undertakings to expand and improve their production potential and to promote a policy of using natural resources rationally and avoiding their unconsidered exhaustion;

(e) promote working conditions and improved standard of living for the workers in each of the industries for which it is responsible;

(f) promote the growth of international trade and ensure that equitable limits are 
observed in export pricing; and

(g) promote the orderly expansion and modernization of production, and the improvement of quality, with no protection against competing industries that is not justified by improper action on their part or in their favour.

The aims of the Euratom Treaty are to:

(a) promote research and ensure the dissemination of technical information;

(b) establish uniform safety standards to protect the health of workers and the general public and ensure that they are applied;

(c) facilitate investments and ensure, particularly by encouraging ventures on the part of the undertakings, the establishment of the basic installations necessary for the development of nuclear energy in the Community;

(d) ensure that all users in the Community receive a regular and equitable supply of ores and nuclear fuels;

(e) make certain, by appropriate supervision, that nuclear materials are not diverted to purposes other than those for which they are intended;

(t) exercise the right of ownership conferred upon it with respect to special fissile materials;

(g) ensure wide commercial outlets and access to the best technical facilities by the creation of a common market in specialized materials and equipment, by the free movement of capital for investment in the field of nuclear energy and by freedom of employment of specialists within the Community;

(h) establish with other countries and international organizations such relations as will foster progress in the peaceful use of nuclear energy.

\section{C- IMPLICATIONS FOR TURKEY}

The aims of the two Treaties clearly outline the implications for the Member States. It needs to be stressed, though, that Turkey would benefit from membership in many ways. First of all she would gain access to the two markets and thus obtain a substantial economic benefit. She would also participate in the technological progress fostered by both Treaties, especially Euratom.

Next to the access to markets is the advantage to the Turkish worker employed in coal and steel industries but this would also impose a corresponding burden on the employers. 
The atomic energy presents a particular problem to modern society. Although it is still relatively undeveloped and very dangerous, it is in reality the source of energy of the future, the more so that the improved standards of living depend greatly on the use of energy. While Turkey may have sufficient natural resources to develop to satisty the country's needs she must keep abreast of the developments in the nuclear sector. Membership of the Euratom offers great advantages if not for the development of a national atomic energy policy at least for the advance of science and technology. Turkish scientists would certainly welcome access to the facilities available at Euratom not only for the sake of science itself but also for Turkey's future. 